\title{
EXPERIMENTAL PATHOGENICITY OF MYCOPLASMA BOVIGENITALIUM ISOLATED FROM BULLS IN LABORATORY RATS AND TREATMENT WITH ANTIBIOTIC NANOPARTICLES
}

\author{
FATHI, A. ${ }^{1}$; ALMUHAMMADY, A. ${ }^{2}$; MONA, M. SOBHY ${ }^{3}$ AND MARWA, S. KHATTAB ${ }^{4}$ \\ ${ }^{1}$ Immunity Unit, Animal Reprod. Res. Inst. ARC, Giza, Egypt. \\ 2 Arab Center for Nanotechnology, Cairo. \\ ${ }^{3}$ Reproductive Diseases Dept., Animal Reprod. Res. Inst. ARC, Giza, Egypt. \\ ${ }^{4}$ Pathology Dept. Fac. of Vet. Med. Cairo Univ.
}

Received: 31 December 2019; Accepted: 31 January 2020

\begin{abstract}
Mycoplasmas are resistance many types of antibiotics, it is very difficult to fight infection resulting in high morbidity. Nanoparticles are a viable alternative to antibiotics and appear to have high potential to solve the problem of bacterial drug resistance. The current study evaluated antimicrobial activity of tilmicosin with carbon nanoparticles on Mycoplasma bovigenitalium in vitro and in vivo laboratory rats. Twenty male albino Wistar rats with average body weight $100 \mathrm{~g}$ were used, divided into four groups (five rats per group). Group 1 was control negative. Group 2 was infected by intraperitoneal injection of M.bovigenitalium at a dose of $10^{5} \mathrm{CFU} / \mathrm{mL}$. Group 3 was infected by $M$. bovigenitalium $\left(10^{5} \mathrm{CFU} / \mathrm{mL}\right)$ and treated with tilmicosin only $(0.5 \mathrm{mg} / \mathrm{body}$ weight $)$. Group 4 infected by $M$. bovigenitalium and treated with tilmicosin + Carbon nanoparticle $(0.35 \mu \mathrm{g} / \mathrm{ml})$. Tissue samples of testis were collected and fixed in $10 \%$ neutral formalin buffer for histopathology. In Group 1 the testis exhibited normal histological structure. In Group 2 the testis demonstrated massive neutrophilic infiltration in the seminepherous tubules and interstitial tissue and complete necrosis of other tubules. Furthermore, there were areas in seminepherous tubules showed germ cell degeneration and multinucleated giant cell formation. Germ cell necrosis, multinucleated giant cell formation in seminepherous tubules and thickening of interstitial tissue with edema and leukocytes infiltration were also recorded. Bacterial aggregation was observed in the interstitial tissue. In Group 3 there were edema, multinucleated giant cell formation in seminepherous tubules and thickening of interstitial tissue with edema and leukocytes infiltration. Group 4, the seminiferous tubules were lined by spermatogenic cells to sperm formation. Advanced research must be done on antimicrobial nanoparticles will help in control of Mycoplasma infection in bovine.
\end{abstract}

Keywords: Mycoplasma bovigenitalium, antibiotic, Carbon nanoparticles.

\section{INTRODUCTION}

Mycoplasma microorganisms have been incriminated in various diseases of animals and humans in recent past and it gained importance owing to the inability to diagnose and difficulty to treat (Yatoo et al., 2018). Mycoplasma is a small prokaryotes lacking cell wall which results in a disease known as mycoplasmosis (Kumar et al., 2011). 32 species of Mycoplasma including $M$. bovigenitalium were reported to be of veterinary importance (Auliffe et al., 2003) whereas there are around 7 species of Mycoplasma reported to cause disease in humans (Embree and Embil 1980).

Corresponding author: Dr. MONA, M. SOBHY

E-mail address: monagabr17@yahoo.com

Present address: Reproductive Diseases Dept., Animal Reprod. Res. Inst. ARC, Giza, Egypt
Mycoplasma has been associated with reproductive disorders as vulvovaginitis, infertility, endometritis and dystocia (Ghanem et al. 2013). The highly contagious nature of Mycoplasma spp., their poor responsiveness to treatment and culling for affected stock (Hermeyer et al., 2012). Mycoplasma bovigenitalium is common in semen, prepuce and vagina of cattle (Parsonson et al., 1974). M. bovigenitalium was found to be incriminated in reproductive disorders in cattle but there was no clinical or diagnostic evidence (Nicholas and others 2008).

Mycoplasma bovigenitalium has been isolated from infertile cattle, and seroreactions to $M$. bovigenitalium antigen was more common among infertile cattle (Catania et al., 2014). M. bovigenitalium has been isolated from cattle associated with reduced fertility, endometritis and granular vulvovaginitis, also from semen samples and from the respiratory tract (Nicholas and others 2008). A previous study 
reported that, $9.29 \%$ of cows were positive for $M$. bovigenitalium (Macêdo et al., 2018). However, the pathogenicity of the most commonly isolated Mycoplasma bovigenitalium, from bulls is still vague.

Treatment of Mycoplasma is difficult due to lack a cell wall and resistant to some commonly used antibiotics (Marouf et al., 2011). Tilmicosin which is a semisynthetic 16-member macrolide antibiotic is widely used in veterinary medicine (Zhang et al., 2016). Tilmicosin has an antimicrobial activity by inhibiting the protein synthesis of susceptible bacteria through binding with the 50S subunits in the ribosome to block transpeptidation and/or mRNA displacement (Kang et al., 2015). Tilmicosin has a broad efficacy spectrum, particularly against Mycoplasma (Ziv et al., 2010). M. bovigenitalium were found to be sensitive to pirlimycin, danofloxacin, enrofloxacin, oxytetracycline, tilmicosin and tylosin, but not to kanamycin (Kawai et al., 2014). Therefore the rapid and accurate diagnosis is very important for control and prevention of disease outbreaks (Parker et al., 2018).

Prevalence of drug-resistant bacteria decreases effectiveness of treatments. New improvements in this problem based on metallic nanoparticles represent an effective solution for overcoming bacterial resistance (Allahverdiyev et al., 2011). The antibacterial mechanisms of nanoparticles (NPs) are oxidative induction, metal ion release, and nonoxidative (Wu et al., 2016). The multiple simultaneous mechanisms of action against microbes would require multiple simultaneous gene mutations in the bacterial cell for antibacterial resistance to develop; therefore, it is difficult for bacterial cells to become resistant to NPs (Wang et al., 2017).

Carbon-based nanoparticles used in biomedical applications in drug and gene delivery. The application as drug delivery is very common in carbon nanoparticles, especially the grapheme nanoparticles. The structure of six-atom rings can be considered as a planar aromatic macromolecule loading capability to a variety of drugs (Yun and Huang, 2016).

Mycoplasma microorganisms are of major concern nowadays due to the emerging antibiotic resistance of Mycoplasma which would result in outbreaks and help in spreading the infection (Yatoo et al., 2019). Therefore, the aim of this study was to evaluate the antimicrobial activity of tilmicosin and tilmicosin nanoparticles on Mycoplasma bovigenitalium in vivo using laboratory rats.

\section{MATERIALS AND METHODS}

Animals:

Twenty male albino Wistar rats with average body weight $100 \mathrm{~g}$ were used. The animals were housed in plastic cages at room temperature $25-27 \mathrm{C}^{\circ}$, and relative humidity $50-60 \%$. Rats had free access to water and maintenance ration. This study was performed in accordance with the Institutional Animal Use and Care Committee (IACUC) guidelines, Cairo University.

\section{Bacterial strain:}

Mycoplasma bovigenitalium was obtained from Animal Reproduction Research Institute, Agriculture Research Center in Giza Egypt.

\section{Antibiotic nanoparticle preparation:}

Antibiotic tilmicosin with carbon nanoparticles were kindly obtained from Dr. Abdel Salam Almuhammady Arab Center for Nanotechnology, Cairo University. Scanning electron microscopy (Hitachi S2150, Krefeld, Germany) was used to image the size and morphology of the Carbon nanoparticles.

\section{Experimental design:}

Twenty rats were divided into four groups (five rats per group).

Group 1 was control negative.

Group 2 was infected by intraperitoneal injection of M.bovigenitalium at a dose of $10^{5} \mathrm{CFU} / \mathrm{mL}$.

Group 3 was infected by $M$. bovigenitalium $\left(10^{5}\right.$ $\mathrm{CFU} / \mathrm{mL})$ and treated with tilmicosin only $(0.5$ $\mathrm{mg} /$ body weight).

Group 4 infected by $M$. bovigenitalium and treated with tilmicosin + Carbon nanoparticle $(\mathbf{0 . 3 5} \mu \mathrm{g} / \mathrm{ml})$.

\section{Histopathology:}

Tissue samples of testis were collected and fixed in $10 \%$ neutral formalin buffer. After fixation, tissues were processed by paraffin embedding technique and sectioned by microtome (Leica 2135 , Germany) at 3 $\mu \mathrm{m}$ thick sections. Tissue sections were then stained by hematoxylin and eosin stain and examined by light microscope (Olympus XC30, Tokyo, Japan). Lesions were photographed by digital Camera (Olympus XC30, Tokyo, Japan).

\section{RESULTS}

\section{Macroscopic findings:}




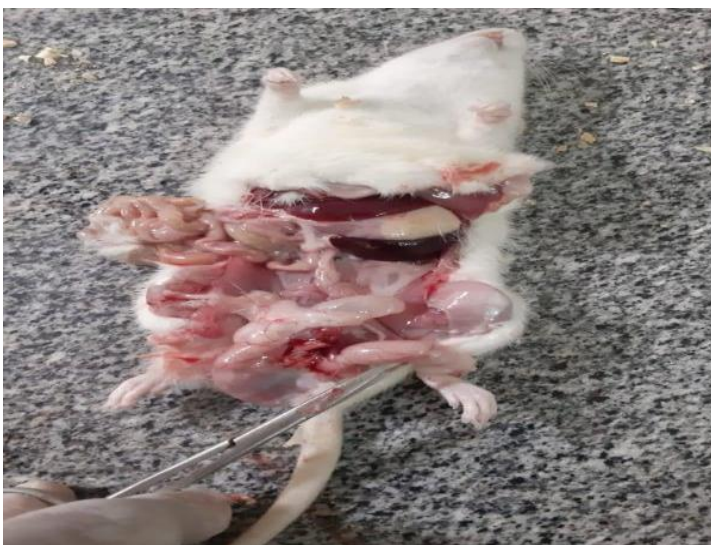

Photo 1: Group 1 as control negative with normal testis.

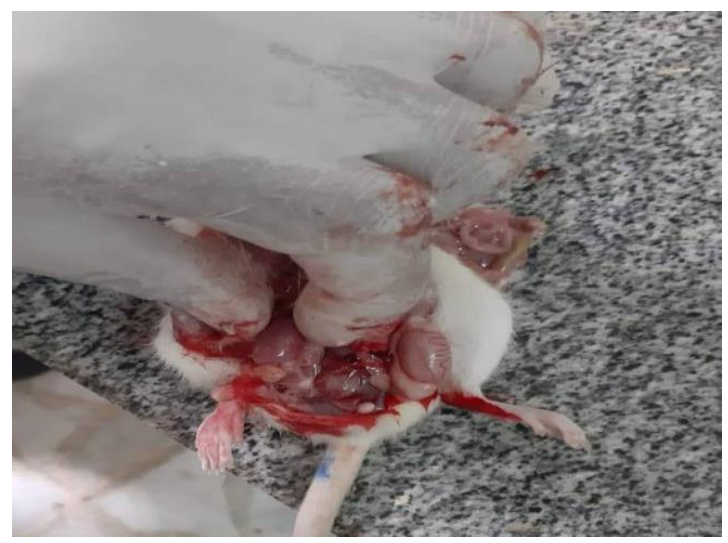

Photo 3: Group 3 infected by $M$. bovigenitalium and treated with tilmicosin only showed mild congestion in the left testis.

\section{Histopathological findings:}

In the Group 1 (control group), the testis exhibited normal histological structure in which the seminiferous tubules are lined by spermatogenic cells up to sperm formation (Fig. 1).

In Group 2 (infected group), the testis demonstrated massive neutrophilic infiltration in the seminepherous tubules and interstitial tissue and complete necrosis of other tubules (Fig. 2). Furthermore, there were areas in which the seminepherous tubules showed germ cell degeneration and multinucleated giant cell formation (Fig. 3). Germ cell necrosis, multinucleated giant cell formation in seminepherous tubules and thickening of interstitial tissue with edema and leukocytes

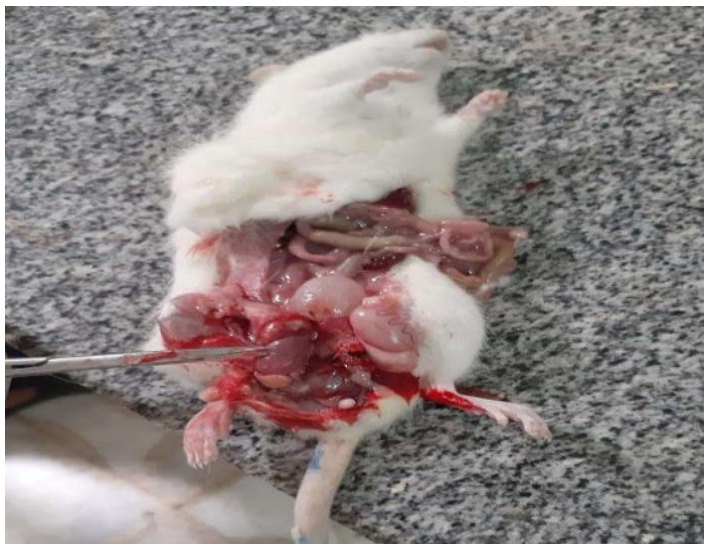

Photo 2: Group 2 infected I/P with M.bovigenitalium showed congested left testis and enlargement of right testis.

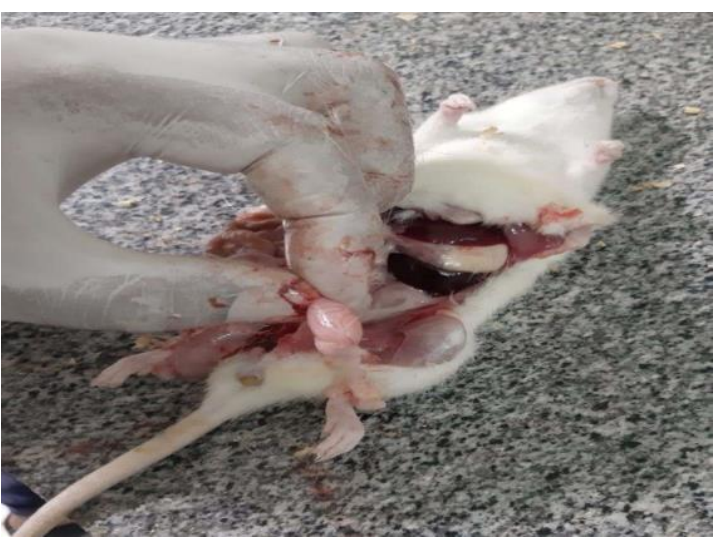

Photo 4: Group 4 infected by $M$. bovigenitalium, treated with tilmicosin and Carbon nanoparticle.

infiltration were also recorded. Bacterial aggregation was observed in the interstitial tissue (Fig. 4).

In Group 3 inoculated with $M$. bovigenitalium and treated with tilmicosin only, there were edema, multinucleated giant cell formation in seminepherous tubules and thickening of interstitial tissue with edema and leukocytes infiltration were demonstrated (Fig. 5).

Group 4 infected by $M$. bovigenitalium and treated with tilmicosin + Carbon

Nanoparticles the seminepherous tubules are lined by spermatogenic cells to sperm formation (Fig. 6). 


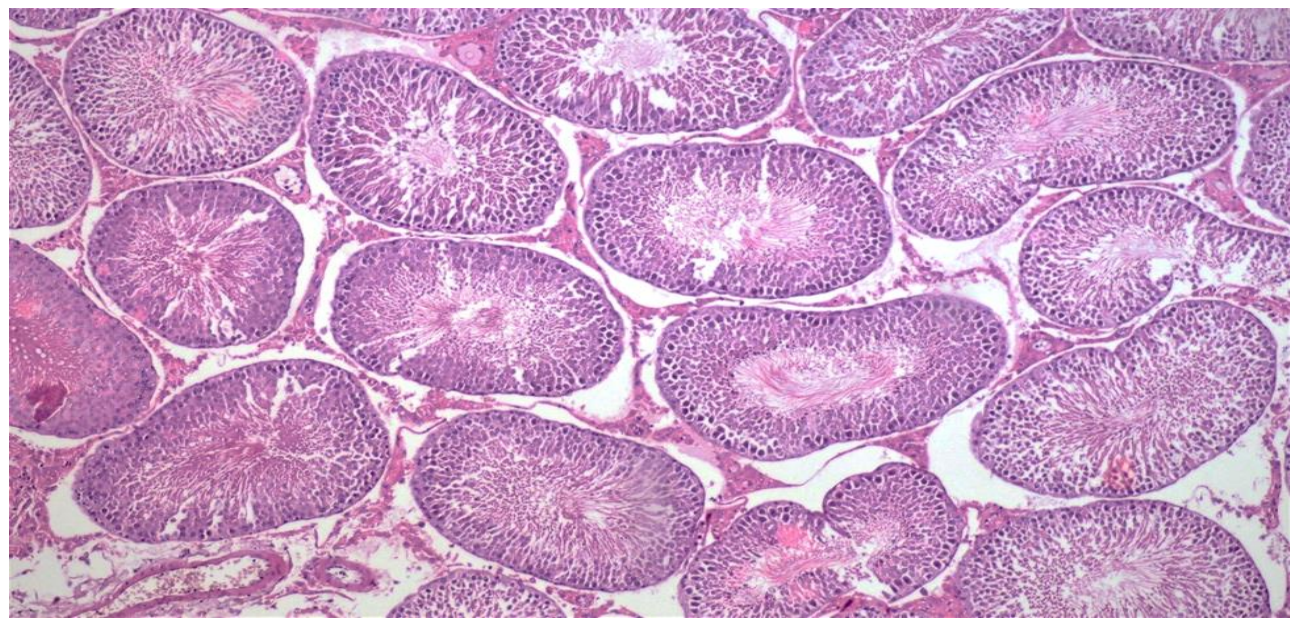

Fig. 1: Testis of rat in Group 1 (control group) showing normal histological structure in which the seminepherous tubules lined by spermatogenic cells up to sperm formation ( $\mathrm{H}$ and $\mathrm{E}$ stain $\mathrm{X} \mathrm{100)}$.

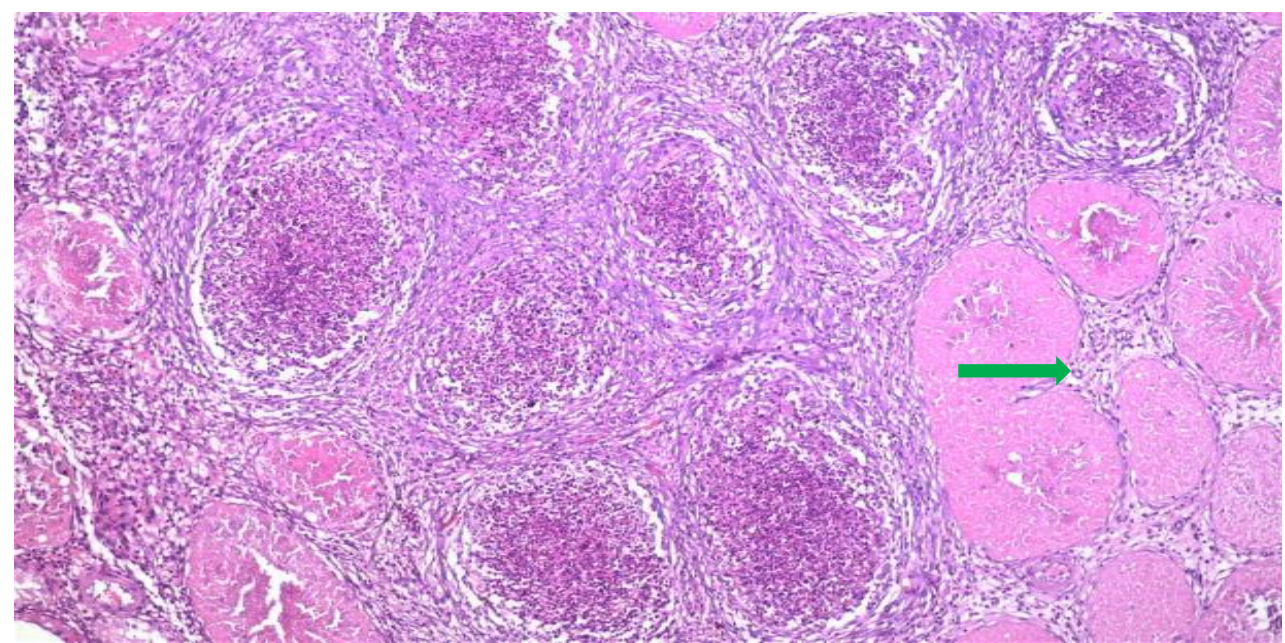

Figure 2: Testis of rat in Group 2 (infected group) showing massive neutrophilic infiltration in the seminepherous tubules and interstitial tissue (arrow head) and complete necrosis of other tubules (arrow) (H and E stain X 100).

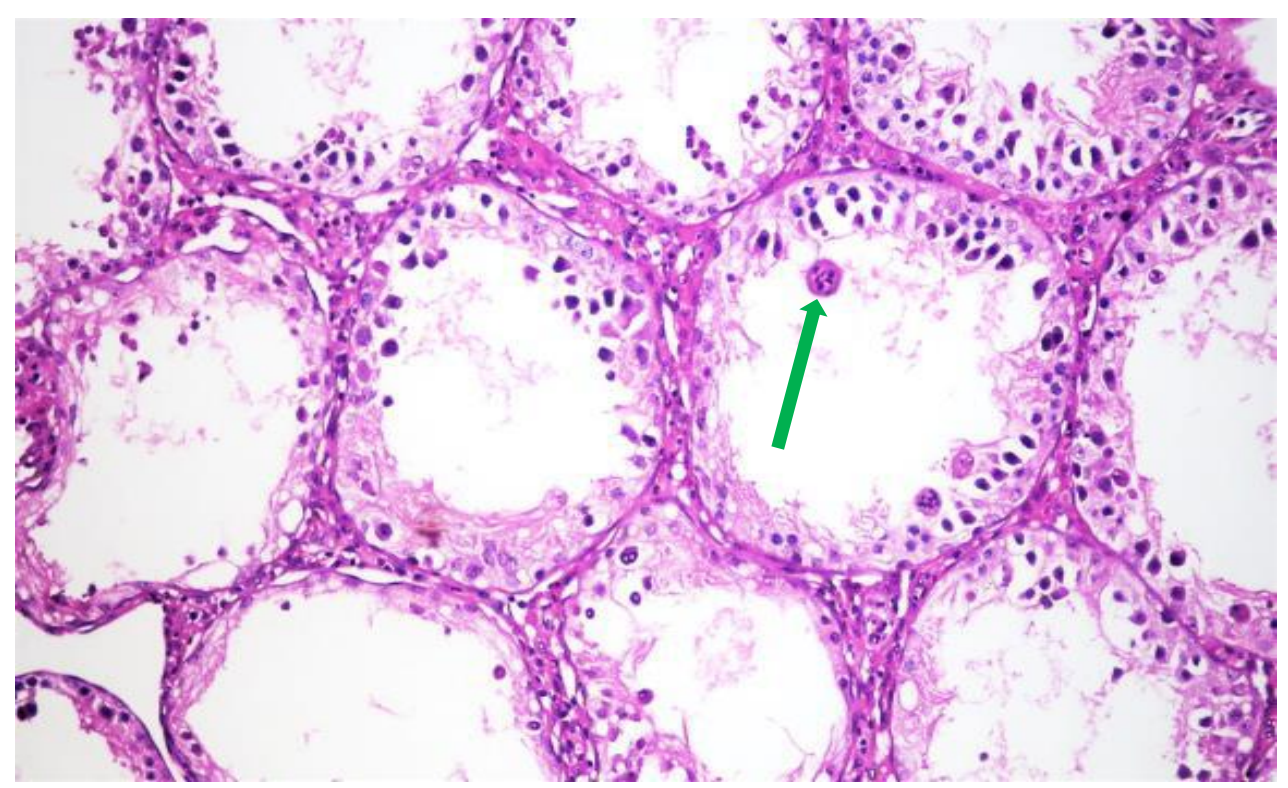

Figure 3: Testis of rat in Group 2 showing germ cell degeneration and multinucleated giant cell formation (arrow) in seminepherous tubules (H and E stain X 250). 


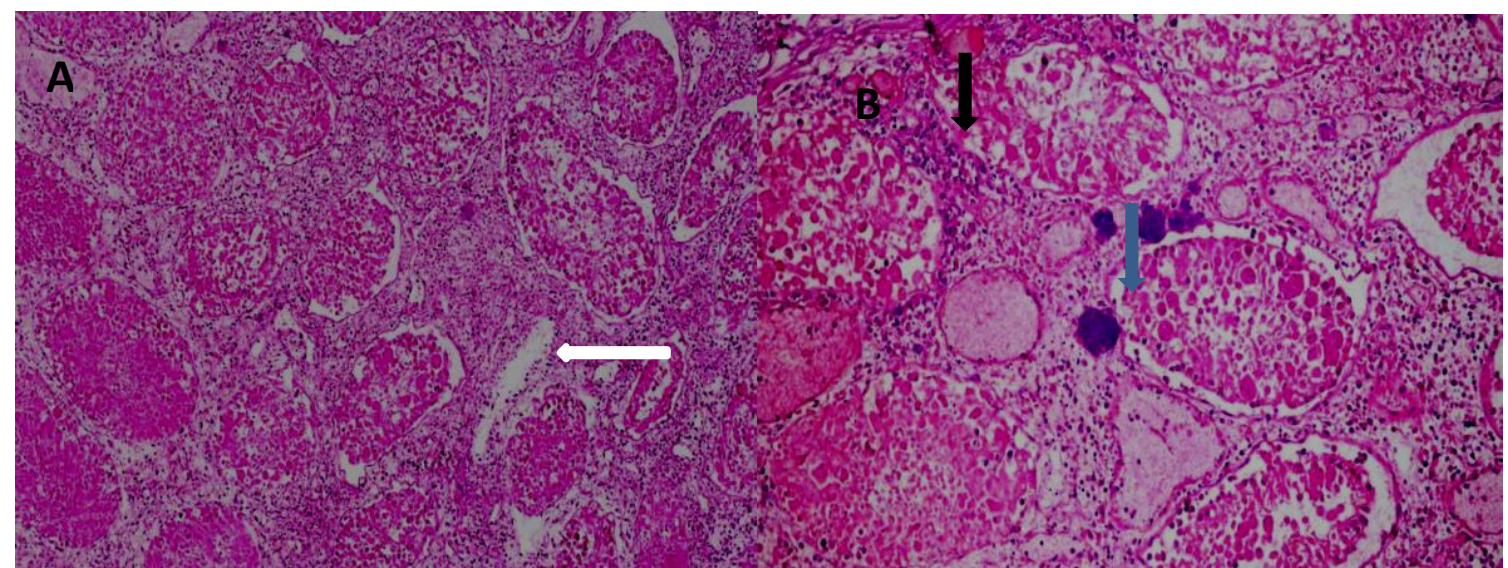

Figure 4 (A \& B): Testis of rat in Group 2 showing germ cell necrosis, multinucleated giant cell formation (black arrow) in seminepherous tubules and bacterial aggregation in the interstitial tissue (white arrow) (H and E stain X 100).

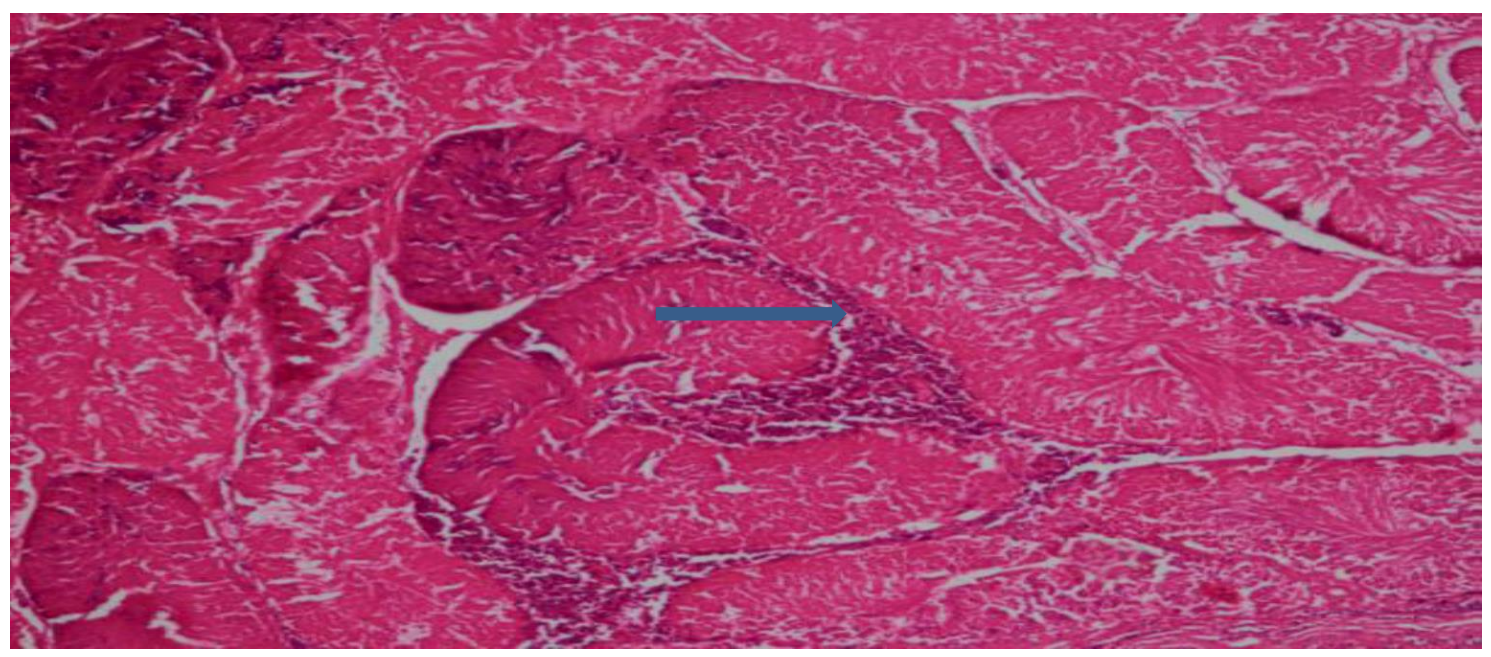

Figure (5): Group 3 testis of rat showing few leukocytic cells in the seminepherous tubules (H and E stain X 100).

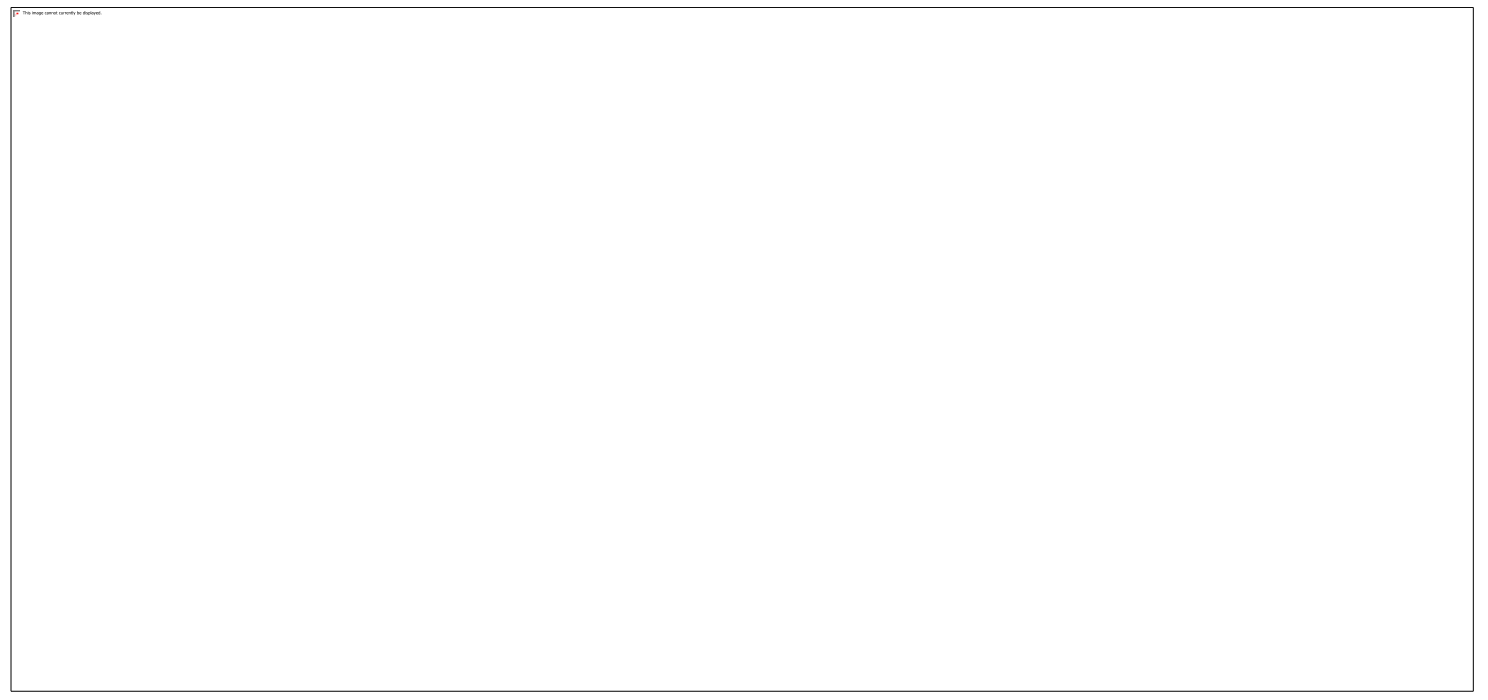

Figure (6): Group 4 testis of rat showing normal histological structure (H and E stain X 250). 


\section{DISCUSSION}

Mycoplasmas can cause serious disease in cattle herds resulting in significant negative economic and welfare impacts (Parker et al., 2018). Mycoplasma bovigenitalium has been associated with infertility, abortion, endometritis, seminal vesiculitis, and impaired spermatozoa motility in cattle (Ruhnke, 1994). It is common in semen, prepuce and vagina of cattle (Parsonson et al., 1974). Blom and Ernø (1967) isolated $M$. bovigenitalium, from a case of bovine seminal vesiculitis. Mycoplasmas are difficult to isolate from tissues highly contaminated with other bacteria (Thiede et al., 2002). Mycoplasmas have ability to modulate host immune responsiveness enabling them to suppress or evade host defense mechanisms and establish chronic, persistent infection (Razin et al., 1998).

NPs can combat bacterial and microbial resistance also can act as a "medium and carrier" of antibiotics. NP carriers can help to target antibiotics to an infection site, minimize side effects and blood drug level maintained in large range that can exceed the maximal tolerated dose (Wu et al., 2017). Carbonbased nanoparticles graphene, has a large surface area and available $\pi$ electrons, which make a smart nanomaterial for a wide range of biomedical applications, including drug delivery, biomolecules sensing, cancer therapy and so on (Chen et al., 2018).

In Group 2 (infected group), the testis demonstrated massive neutrophilic infiltration in the seminepherous tubules and interstitial tissue and complete necrosis of other tubules (Fig. $2 \&$ Photo, 2). Furthermore, there were areas in which the seminepherous tubules showed germ cell degeneration and multinucleated giant cell formation (Fig. 3). Germ cell necrosis, multinucleated giant cell formation in seminepherous tubules and thickening of interstitial tissue with edema and leukocytes infiltration were also recorded. Bacterial aggregation was observed in the interstitial tissue (Fig. 4).

In Group 3 inoculated with $M$. bovigenitalium and treated with tilmicosin only, there were edema, multinucleated giant cell formation in seminepherous tubules and thickening of interstitial tissue with edema and leukocytes infiltration were demonstrated (Fig. 5 and photo, 3).

Group 4 infected by $M$. bovigenitalium and treated with tilmicosin + Carbon Nanoparticles the seminiferous tubules are lined by spermatogenic cells to sperm formation (Fig. 6 and photo, 4). Carbon, CNTs have attracted various drug molecules into the living cells because their natural morphology facilitates non-invasive penetration across the biological membranes (Liu et al., 2013). Noncovalent interaction facilitates the controlled release of the drug in the acidic condition of lesion sites (Panczyk et al., 2016).
Advanced research must be done on antimicrobial nanoparticles will help in control of Mycoplasma infection in bovine.

\section{REFERENCES}

Allahverdiyev, A.M.; Kateryna, V.K.; Emrah, S.A.; Malahat, B. and Rafailovich, M. (2011): Coping with antibiotic resistance: combining nanoparticles with antibiotics and other antimicrobial agents. Expert Rev. Anti-Infect. Ther. 9(11), 1035-1052.

Auliffe, L.; Ellis, R.J.; Ayling, R.D. and Nicholas, R.A. (2003): Differentiation of Mycoplasma species by $16 \mathrm{~S}$ ribosomal DNA PCR and denaturing gradient gel electrophoresis fingerprinting. Journal of Clinical Microbiology, 41(10): 4844-4847.

Blom, E. and Ernф, H. (1967): Mycoplasmosis: Infections of the genital organs of bulls. Acta Veterinaria Scandinavia 8: 186-188.

Chen, F.; Gao, W.; Qiu, X.; Zhang, H.; Liu, L. and Luo, Y. (2018): Graphene quantum dots in biomedical applications: recent advances and future challenges. Front. Lab. Med. 1, 192199.

Embree, J.E. and Embil, J.A. (1980): Mycoplasmas in diseases of humans. Canadian Medical Association Journal, 123(2): 105.

Hermeyer, K.; Peters, M.; Brugmann, M.; Jacobsen, B. and Hewicker-Trautwein, M. (2012): Demonstration of Mycoplasma bovis by immunohistochemistry and in situ hybridization in an aborted bovine fetus and neonatal calf. J Vet Diagn Invest. 24: 364369.

Kang, S.; Li, Z.; Yin, Z.; Jia, R.; Song, X.; Li, L.; Chen, Z.; Peng, L.; Qu, J. and Hu, Z. (2015): The antibacterial mechanism of berberine against Actinobacillus pleuropneumoniae. Nat. Prod. Res.; 29: 2203- 2206.

Kawai, K.; Higuchi, H.; Iwano, H.; Iwakuma, A.; Onda, K.; Sato, R.; Hayashi, T.; Nagahata, $H$. and Oshida, T. (2014): Antimicrobial susceptibilities of Mycoplasma isolated from bovine mastitis in Japan. Anim Sci J. 85(1): 96-9.

Kumar, P.; Roy, A.; Bhanderi, B.B. and Pal, B.C. (2011): Isolation, identification and molecular characterization of Mycoplasma isolates from goats of Gujarat State, India. Veterinarski Arhiv, 81(4): 443-458.

Liu, Y.; Zhao, Y.; Sun, B. and Chen, C. (2013): Understanding the toxicity of carbon nanotubes. Acc. Chem. Res. 46, 702-713.

Macêdo, A.A.M.; Oliveira, J.M.B.; Silva, B.P.; Borges, J.M.; Soares, L.B.F.; Silva, G.M.; Santos, S.B.; Mota, R.A. and Pinheiro-Júnior, J.W. (2018): Occurrence of Mycoplasma bovigenitalium and Ureaplasma diversum in dairy cattle from to Pernambuco state, Brazil. 
Arq. Bras. Med. Vet. Zootec. Vol.70, No.6, pp.1798-1806.

Marouf, S.A.; Mohamed, K.F. and Eljakee, J.K. (2011): "Detection of Mycoplasma bovis and Mycoplasma bovigenitalium in Cattle and Buffalo in Egypt Using Dot ELISA and PCR with Anti -Microbial Trials", European Journal of Biological Sciences, vol. 25, pp. 136-146.

Nicholas, R.; Ayling, R. and McAuliffe, L. (2008): Reproductive Diseases of Ruminants, Mycoplasma Diseases of Ruminants. Wallingford: CAB International, pp $208-215$.

Panczyk, T.; Wolski, P. and Lajtar, L. (2016): Coadsorption of doxorubicin and selected dyes on carbon nanotubes. Theoretical investigation of potential application as a pH-controlled drug delivery system. Langmuir 32, 47194728.

Parker, A.M.; Paul, A.S.; Mark, S.H.; Bosward, K.L. and House, J.K. (2018): A review of mycoplasma diagnostics in cattle. J. Vet Intern Med. 32(3): 1241-1252.

Parsonson, I.M.; Al-Aubaidi, J.M. and Mcentee, K. (1974): Mycoplasma bovigenitalium: Experimental induction of genital disease in bulls. Cornell Veterinarian 64: 240-264.

Razin, S.; Yogev, D. and Naot, Y. (1998): Molecular biology and pathogenicity of Mycoplasmas. Microbiology and Molecular Biology Reviews 62: 1094-1156.

Thiede, S.; Spergser, J.; Rosengarten, R.J.; Willi, S. and Wolf, J. (2002): Antibodies against Mycoplasma bovigenitalium in free living European Bison (Bison Bonasus) with balanoposthitis. Journal of Wildlife Diseases, 38(4): 760-763.

Wang, L.L.; Hu, C. and Shao, L.Q. (2017): The antimicrobial activity of nanoparticles: present situation and prospects for the future. International J. of Nanomedicine, Vol. 12, P: 1227-1249.

Wu, J.; Shen, Y.; Jiang, W.; Jiang, W. and Shen, Y. (2016): Magnetic targeted drug delivery carriers encapsulated with $\mathrm{pH}$-sensitive polymer: synthesis, characterization and in vitro doxorubicin release studies. J Biomater Sci Polym Ed. 27(13): 1303-1316.

Yun, S. and Huang, J.J. (2016): Routes for drug delivery: $\quad$ sustained-release devices. Dev Ophthalmol. 55: 84-92.

Yatoo, M.I.; Parray, O.R.; Mir, M.S.; Qureshi, S.; Amin, Z.; Kashoo, M.N.; Fazili, M.U.R.; Tufani, N.A.; Singh, M.; Kanwar, S.C. and Dhama, K. (2018): Mycoplasmosis in small ruminants in India: a review. Journal of Experimental Biology, 6: 2.

Yatoo, M.I.; Oveas, R.P.; Riyaz, A.B.; Muheet, A.G.; Archana, S.; Sandip, C.; Ruchi, T.; Sandip, K.K.; Shoor, V.S. and Kuldeep, D. (2019): Emerging Antibiotic Resistance in Mycoplasma Microorganisms, Designing Effective and Novel Drugs / Therapeutic Targets: Current Knowledge and Futuristic Prospects, J Pure Appl Microbiol.,13(1): 2744.

Zhang, P.; Hao, H.; Li, J.; Ahmad, I.; Cheng, G.; Chen, D.; Tao, Y; Huang, L.; Wang, Y. and Dai, M. (2016): The epidemiologic and pharmacodynamic cutoff values of tilmicosin against Haemophilus parasuis. Front Microbiol, 7: 385.

Ziv, G.; Shem-Tov, M.; Glickman, A.; Winkler, M. and Saran, A. (2010): Tilmicosin antibacterial activity and pharmacokinetics in cows. J. Vet. Pharmacol. Ther. 18, 340-345.

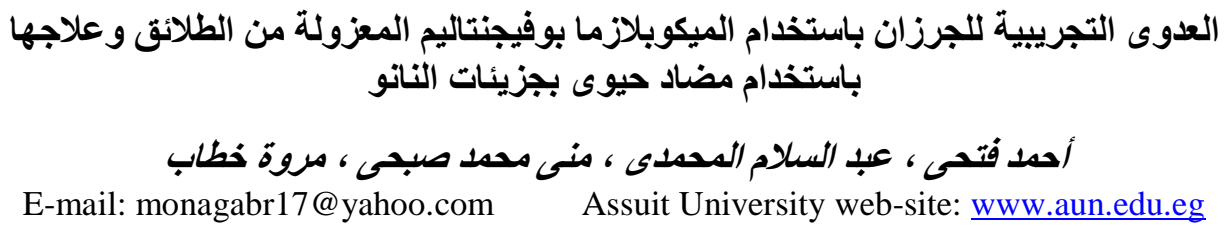

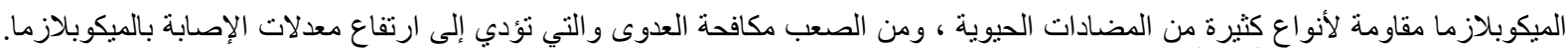

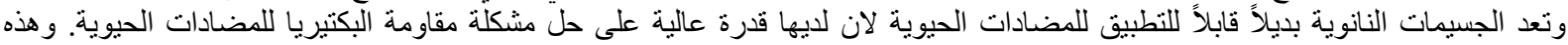

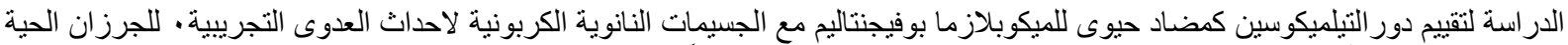

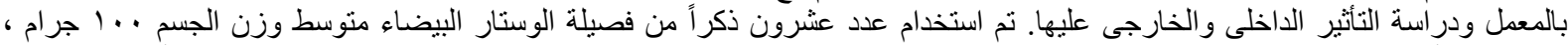

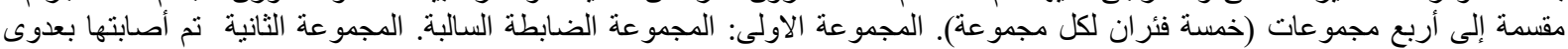

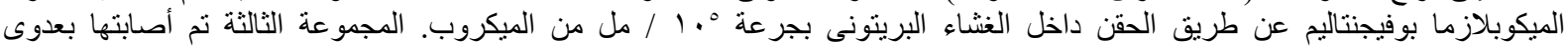

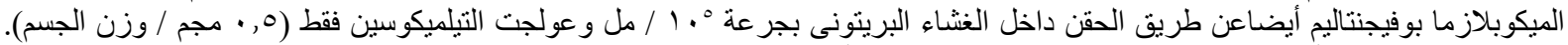

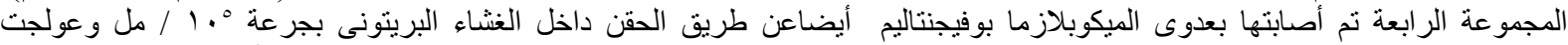

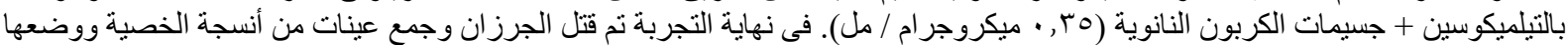

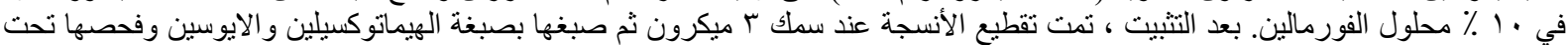

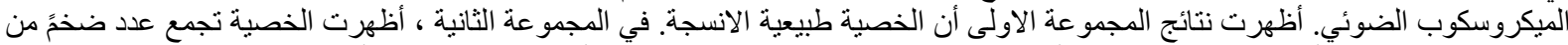

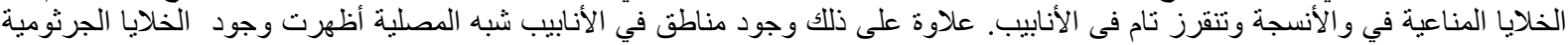

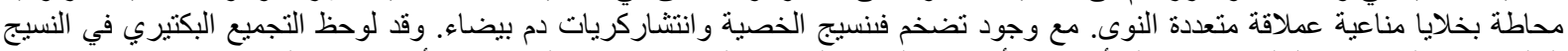

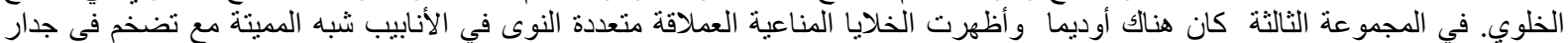

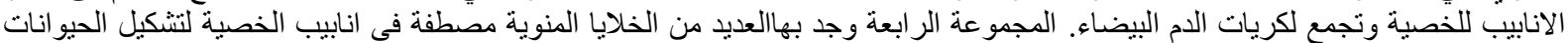

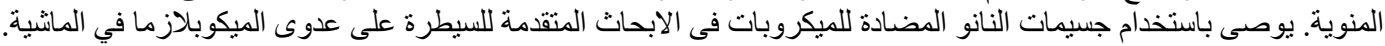

